\title{
Tree Growth Stage and Environment After Pathogen Inoculation Alters Susceptibility of Pear Trees to Phytophthora Canker
}

\author{
S. Laywisadkul ${ }^{*}, 1$, L.H. Fuchigami ${ }^{1}$, C.F. Scagel ${ }^{2}$ and R. G. Linderman ${ }^{2}$
}

${ }^{I}$ Department of Horticulture, Oregon State University, Corvallis, OR, 97331, USA; ${ }^{2}$ U.S. Department of Agriculture, Agricultural Research Service, Horticultural Crops Research Unit, 3420 NW Orchard Avenue, Corvallis, OR, 97330, USA

\begin{abstract}
We investigated whether pear (Pyrus communis L. OHF97) tree growth stage, nitrogen (N) status, wound age, and infection environment influences susceptibility to Phytophthora syringae Klebahn. Actively growing trees were susceptible to the pathogen when inoculated before terminal budset and cooler temperatures increased disease severity. In the autumn, during early stages of dormancy development after budset there was no relationship between temperature after inoculation and susceptibility and as trees became more dormant a negative relationship developed between temperature and susceptibility. Altering tree $\mathrm{N}$ status in the autumn after budset by spraying leaves with urea had no influence on susceptibility, regardless of environmental conditions after inoculation. Lesions developed when fresh wounds $(0 \mathrm{~d}$ to $1 \mathrm{~d}$ old) were inoculated after budset, but as wounds aged they were less susceptible to infection. These results suggest a combination of tree growth stage when inoculated with the pathogen and environmental conditions afterward play important roles in disease development. Differences in susceptibility may be a direct result of temperature on pathogen activity or an indirect effect of temperature on tree metabolic activity. Differences in tree susceptibility related to dormancy development may be related to stem $\mathrm{N}$ status or the ability of trees to produce a barrier to infection after stems are wounded. Surface wounds inflicted during handling after budset may serve as infection locations for $P$ syringae; however the length of time between wound formation and exposure to the pathogen dictates whether infection will occur when trees are in the early stages of dormancy development.
\end{abstract}

Keywords: Dormancy, Phytophthora syringae, Pyrus communis.

\section{INTRODUCTION}

During the winter, Phytophthora syringae Klebahn can cause disease on bare-root deciduous nursery stock in the Pacific Northwest (PNW) region of the USA, especially on trees harvested and stored in coolers or in outdoor sawdust beds [1]. In the PNW, Phytophthora spp. found in stool beds caused stem and root rot disease of apple rootstocks and can potentially act as a primary source of inoculum after transplanting into orchards [1]. Infected rootstock of indigenous inoculum can cause Phytophthora diseases in nursery trees after transplanting can $[2,3]$.

Phytophthora syringae is most active during the cool, rainy months of the year (September to November in the northern hemisphere) $[4,5]$. The reported temperature range for growth of $P$. syringae broad and the minimum temperature for growth is $<5{ }^{\circ} \mathrm{C}$, optimum 15 to $20{ }^{\circ} \mathrm{C}$ and the maximum is $23-25{ }^{\circ} \mathrm{C}$ [4]. Increased activity of the pathogen coincides with the dormancy development of deciduous

*Address correspondence to this author ar the Department of Horticulture, Oregon State University, Corvallis, OR, 97331, USA;

Tel: 66-55-963310; Fax: 66-55-963301;

E-mail: srisangwan@gmail.com trees. Thus some researchers and growers speculate the incidence or severity of the disease may be related to the dormancy status of the tree, while others hypothesize the reason for increased disease during the dormant period is due to the wet-cold environment and not the dormancy status of the tree per se.

Numerous structural and chemical changes occur in trees during seasonal development and these changes can influence tree susceptibility to Phytopthora spp. Responses of trees to Phytopthora spp. can occur when trees are actively growing [6] or when trees are dormant [7]. Tree susceptibility to $P$. syringae has been shown to vary between actively growing and dormant trees, and also vary with plant tissue used for testing. For example, wound inoculation was successfully used to demonstrate $P$. syringae pathogenicity on branches and buds of dormant rhododendrons (Rhododendron spp.) kept at $4{ }^{\circ} \mathrm{C}$, while the attempts to infect branches and buds of actively growing plants with the pathogen failed [8]. Although branches and buds of actively growing plants could not be infected with the pathogen, inoculation of detached leaves from actively growing plants can cause lesions [8].

Climate influences the development of diseases caused by Phytophthora spp., and climate constraints on certain species determine the geographic distribution of diseases they cause [9]. Cold climate restricts pathogenic activities by 
P. cinnamomi Rands in soil but does not appear to restrict the activities of either $P$. syringae, $P$. cactorum (Lebert et Cohn) Schröter, or several other species. The seasonal activities of host plants and the influence of physical factors of the environment determine the time course of epidemics caused by Phytophthora spp. [9]. Nearly all cankers on almond [Prunus dulcis (Mill.) D. A. Webb] trees caused by P. syringae were associated with pruning wounds or injuries created during pruning in late autumn and winter, and infection was unsuccessful on uninjured bark [10]. Fresh wounds on almond trees were more susceptible to infection than aged wounds, and the development of resistance to infection on bark wounds was slowed when temperature during bark wounding were low [11].

Wound inoculation is generally used in experiments with $P$. syringae, because this pathogen is unsuccessful in causing infection through uninjured bark [8, 10, 12]. Phomopsis amygdali (Del.) J. J. Tuset \& T. Portilla, causal agent of constriction cankers, initiates infections of peach [Prunus persica (L.) Batch.] twigs through fresh leaf scars in fall and bud scale scars and flowers in spring [13]. In artificial inoculations of $P$. syringae in rhododendrons, wounds and low temperatures were prerequisite for infection [8]. Bare-rooted deciduous nursery trees that are defoliated before harvesting generally survive the stresses associated with handling and storage better than trees with leaves. Surface wounds, inflicted when trees are harvested and leaf scars caused by artificial or natural defoliation and subsequent handling, serve as potential infection locations for $P$. syringae $[5,10$, 12].

Using field grown pear trees and an in vivo infection assay for $P$. syringae, the specific objectives of this study were to determine whether tree susceptibility to infection by the pathogen is altered by: (1) stage of plant growth after terminal bud set; (2) environmental conditions (primarily temperature) after dormant trees are inoculated with the pathogen; and (3) environmental conditions (primarily temperature) after actively growing trees are inoculated with the pathogen. Additionally, we also evaluated whether the wound age or increased tree nitrogen status during the autumn altered susceptibility of dormant trees to $P$. syringae infection.

\section{MATERIALS AND METHODS}

\section{Inoculum Production and Wound Inoculation}

Stock cultures of $P$. syringae (isolated from Kalmia latifolia L. by Robert Linderman, USDA-ARS, Corvallis, OR) were maintained on V8 juice agar (V8 A) medium in the dark at $20^{\circ} \mathrm{C}$. To prepare the medium, $4 \mathrm{~g}$ calcium carbonate added to $340 \mathrm{ml}$ of $\mathrm{V} 8$ juice was heated and then filtered through cheese cloth. Then $100 \mathrm{ml}$ of the filtered juice was added to $17 \mathrm{~g}$ of agar and distilled water added to 1 liter before autoclaving $\left(121{ }^{\circ} \mathrm{C}, 20 \mathrm{~min}\right)$. Fresh cultures were prepared 7 to $10 \mathrm{~d}$ before inoculation by transferring $4 \mathrm{~mm}$ dia. agar plugs to plates containing V8A and incubated in the dark at $20{ }^{\circ} \mathrm{C}$. Wounds on stems were inoculated using mycelial plugs (4 $\mathrm{mm}$ dia.) taken from the actively growing margin of colonies of $P$. syringae growing on V8A. Plugs with or without the pathogen were placed into a wound made with a cork borer (4 $\mathrm{mm}$ dia.). Wounds were wrapped with Parafilm ${ }^{\circledR}$ after inoculation.

\section{Experiment 1: Tree Susceptibility During Dormancy De- velopment in Autumn}

Pear OHF-97 rootstock were planted into $3.8 \mathrm{~L}$ containers containing a mixture of Douglas-fir bark, peat moss, and pumice $(1: 1: 1)$ on 21 May 2003. The trees were grown in a lath house at Oregon State University, Corvallis, OR $\left(44^{\circ} 30^{\prime}\right.$ $\left.\mathrm{N}, 123^{\circ} 17^{\prime} \mathrm{W}\right)$ and trained to a single stem. Trees were fertigated with $200 \mathrm{mg} \mathrm{l}^{-1} \mathrm{~N}$ using Plantex ${ }^{\circledR}$ 20-20-20 with micronutrients (Plantex Corp., Ontario, Canada) once a week, from 6 June to 5 September 2003. After terminal buds had set (1 October 2003) 100 trees were selected for uniformity based on stem diameter (7-8 mm.), divided into two groups of 50 trees, and moved to either the lathe house (LH) or greenhouse $(\mathrm{GH})$ to produce trees in different stages of dormancy development. The LH trees were kept in natural conditions in a lathe house with transparent plastic over the roof and the $\mathrm{GH}$ trees were exposed to $16 \mathrm{~h} / 8 \mathrm{~h}$ light/dark and 21 ${ }^{\circ} \mathrm{C} / 15{ }^{\circ} \mathrm{C}$ day/night. The light in the greenhouse was extended from 6:00 a.m. to 10:00 pm with (1000 watt) sodium vapor lamps placed 2 meters above the top of the benches. Every two weeks ten trees from each location ( $\mathrm{LH}$ or $\mathrm{GH}$ ) were inoculated with $P$. syringae and moved to one of two locations after inoculation. After trees were inoculated five trees from the LH were maintained in the $\mathrm{LH}(\mathrm{LH} / \mathrm{LH})$ and five trees were moved to the $\mathrm{GH}(\mathrm{LH} / \mathrm{GH})$. Five trees from the $\mathrm{GH}$ were maintained in the $\mathrm{GH}$ after inoculation $(\mathrm{GH} / \mathrm{GH})$ and five trees were moved to the LH $(\mathrm{LH} / \mathrm{LH})$.

Stems were inoculated in wounds with $P$. syringae on 7 October 2003, 21 October 2003, 11 November 2003, 25 November 2003, and 9 December 2003. Inoculum production and wound inoculation was performed as described above. Three wounds were made on the stem of each tree: two wounds were inoculated with $P$. syringae grown on V8 A and one wound was inoculated with V8 A without the pathogen. Disease incidence (percentage of wounds with lesions) and disease severity (length of lesion) was measured on trees 8 weeks after inoculation. Stems of trees inoculated on 7 October 2003, 21 October 2003, 11 November 2003, 25 November 2003, and 9 December 2003 were assessed on 2 December 2003, 16 December 2003, 6 January 2004, 20 January 2004, and 3 February 2004, respectively.

\section{Experiment 2: Tree Susceptibility and Infection Envi- ronment in Winter}

Pear OHF-97 rootstocks were transplanted into $3.8 \mathrm{~L}$ containers containing a mixture of Douglas-fir bark, peat moss, and pumice $(1: 1: 1)$ in 1 June 2004. The trees were grown in a lath house at OSU and trained to a single stem. Trees were fertigated with $200 \mathrm{mg} \mathrm{l}^{-1} \mathrm{~N}$ using Plantex ${ }^{\circledR} 20$ 20-20 with micronutrients once a week, from 14 June to 18 August 2004. After terminal bud set (mid October) 30 trees were selected for uniformity based on stem diameter (7-8 $\mathrm{mm}$ ), divided into two groups of 15 trees, and moved to either to the $\mathrm{LH}$ or $\mathrm{GH}$ to produce trees in different stages of dormancy development. Conditions in the $\mathrm{LH}$ and GH were the same as described for Experiment 1, above. On 22 January 2005, after natural defoliation of trees in the LH, 15 plants from each location ( $\mathrm{LH}$ or $\mathrm{GH}$ ) were inoculated with 
$P$. syringae and moved to one of three locations after inoculation ( $\mathrm{LH}, \mathrm{GH}, \mathrm{CR})$. After trees were inoculated five trees from the $\mathrm{LH}$ were maintained in the $\mathrm{LH}(\mathrm{LH} / \mathrm{LH})$, five trees were moved to the $\mathrm{GH}(\mathrm{LH} / \mathrm{GH})$, and five trees were moved to a cold room $\left(\mathrm{CR} ; 4^{\circ} \mathrm{C}\right.$, dark and each tree was covered with polyethylene bag to prevent desiccation) (LH/CR); Five trees from the $\mathrm{GH}$ were maintained in the $\mathrm{GH}$ after inoculation $(\mathrm{GH} / \mathrm{GH})$, five trees were moved to the $\mathrm{LH}(\mathrm{GH} / \mathrm{LH})$ or five trees were moved to the $(\mathrm{GH} / \mathrm{CR})$.

Stems were inoculated with $P$. syringae on 22 January 2005 . Inoculum production and wound inoculation was performed as described above. Three wounds were made on the stem on each tree: two wounds were inoculated with $P$. syringae grown on V8A and one wound was inoculated with V8A without the pathogen. Disease incidence (percentage of wounds with lesions) and disease severity (length of lesion) was measured on trees 8 weeks after inoculation. Stems of trees inoculated on 22 January 2005 were assessed on 19 March 2005.

\section{Experiment 3: Susceptibility of Actively Growing Trees}

Pear OHF-97 rootstocks were transplanted into $3.8 \mathrm{~L}$ containers containing a mixture of Douglas-fir bark, peat moss, and pumice $(1: 1: 1)$ in 1 June 2004 . The trees were grown in a lath house at OSU and trained to a single stem. Trees were fertigated with $200 \mathrm{mg} \mathrm{l}^{-1} \mathrm{~N}$ using Plantex ${ }^{\circledR} 20$ 20-20 with micronutrients once a week, from 14 June to 18 August 2004. During the actively growing period (before terminal bud set, 13 September 2004) 12 trees were selected for uniformity based on stem diameter $(6-7 \mathrm{~mm}$.), inoculated with $P$. syringae, divided into three groups of 4 trees, and moved to either the $\mathrm{LH}, \mathrm{GH}$, or CR. Conditions in the LH, $\mathrm{GH}$, and CR were the same as described above.

Stems were inoculated with $P$. syringae on 13 September 2004 . Inoculum production and wound inoculation was performed as described above. Three wounds were made on one stem on each tree: two wounds were inoculated with $P$. syringae grown on V8 agar and one wound was inoculated with V8 agar without the pathogen. Disease incidence (percentage of wounds with lesions) and disease severity (length of lesion) was measured on trees 4 weeks after inoculation. Stem of trees inoculated on 13 September 2004 were assessed on 11 October 2004.

\section{Experiment 4: Relationships Between Susceptibility, Tree N Status, and Wound Age}

Pear OHF-97 rootstocks were planted into $3.8 \mathrm{~L}$ containers containing a mixture of Douglas-fir bark, peat moss, and pumice $(1: 1: 1)$ on 1 June 2004 . The trees were grown in a lath house (LH) at OSU, Corvallis, OR, USA, trained to a single stem, and fertigated with $200 \mathrm{mg} \mathrm{l}^{-1} \mathrm{~N}$ using Plantex ${ }^{\circledR}$ 20-20-20 with micronutrients once per week from 14 June to 18 August 2004.

After terminal bud set (mid October), 32 trees were selected for uniformity based on diameter $(8-9 \mathrm{~mm})$ and divided into two groups of 16 trees. Leaves on 16 trees were sprayed until run-off with either water or a combination of urea (3\% solution, urea 46-0-0) and $\mathrm{Cu}$-EDTA (1\% solution, Ciba ${ }^{\circledR}$ Librel ${ }^{\circledR} \mathrm{Cu}$ (Cu-EDTA) Ciba) (Urea+CuEDTA) on October 22, 2004. Starting 1 week after spray treatments, stems on 16 trees in each spray treatment were wounded every $7 \mathrm{~d}$ for 5 weeks. Wounds were made on each stem on 29 October 2004, 5 November 5 2004, 12 November 2004, 19 November 2004, and 25 November 2004. Two wounds were made on 26 November 2004. Wounds were made by removing a $4 \mathrm{~mm}$ diameter circle of the bark tissue from stems using a cork borer. On 26 November 2004 all wounds were inoculated with the pathogen, trees were divided into two groups and moved to either the LH or CR. Conditions in the LH and CR were the same as described above.

Trees were inoculated with the pathogen on 26 November 2004. Inoculum production and wound inoculation was performed as described above. Seven wounds were inoculated on the stem of each tree: six wounds of different ages were inoculated with $P$. syringae and one of the two wounds made on 25 November 2005 was inoculated with V8A without the pathogen. Disease incidence (percentage of wounds with lesions) and disease severity (length of lesion) was measured on trees on 21 January 2005 ( 8 weeks after inoculation).

\section{Experimental Designs and Statistical Analyses}

Experiment 1 was a completely randomized design with 3 factors: Growing location before inoculation (LH, GH), time of inoculation $(1,3,5,7,9$ weeks after terminal buds had set), and incubation location after inoculation (LH, GH). Each treatment had 5 replications. Each tree had 2 pathogeninoculated wounds on the same stem. Lesions did not occur on wounds inoculated with on V8A and were therefore not included in analyses. Data were analyzed using KruskalWallis ANOVA to determine whether treatments influenced lesion size and treatment comparisons were made at $\mathrm{P}<0.05$ $\left(\mathrm{K}-\mathrm{W}_{0.05}\right)$.

Experiment 2 was a completely randomized design with two factors: Growing location before inoculation (LH, GH), and incubation location after inoculation ( $\mathrm{LH}, \mathrm{GH}, \mathrm{CR}$ ). Each treatment had 5 replications. Each tree had 2 pathogeninoculated wounds on the same stem. Lesions did not occur on wounds inoculated with on V8A and were therefore not included in analyses. Data were analyzed using analysis of variance (ANOVA) to determine whether treatments influenced lesion size and where indicated by ANOVA, means were separated using Tukey's Honestly Significant Difference at $\mathrm{P}<0.05\left(\mathrm{THSD}_{0.05}\right)$.

Experiment 3 was a completely randomized design with the treatments ( $\mathrm{LH}, \mathrm{GH}, \mathrm{CR})$. Each treatment had 4 replications. Each tree had 2 pathogen-inoculated wounds on the same stem. Lesions did not occur on wounds inoculated with on V-8 agar and were therefore not included in analyses. Data were analyzed using Kruskal-Wallis ANOVA to determine whether lesion size was influenced by the incubation condition and treatment comparisons were made at $\mathrm{P}<0.05$ $\left(\mathrm{K}-\mathrm{W}_{0.05}\right)$.

Experiment 4 was a completely randomized design with 3 factors: foliar treatments (water and Urea+CuEDTA), incubation location (LH and CR), and wound age (0, 1, 7, 14, 21 , and $28 \mathrm{~d}$ ). No lesions occurred on wounds inoculated with only V8A; therefore, only data from wounds inoculated with the pathogen were included in the analyses. Each treatment had 8 replications. Data were analyzed using Kruskal- 
Wallis ANOVA to determine whether treatments influenced lesion size and treatment comparisons were made at $\mathrm{P}<0.05$ $\left(\mathrm{K}-\mathrm{W}_{0.05}\right)$.

All data were tested for homogeneity of variance using Levene's test and for normality using the KolmogorovSmirnov test. When transformation could not be used to correct for lack of homogeneity of variance or normality, nonparametric analyses were applied to the data to test specific hypotheses. The relationships between the lesion size and temperatures were analyzed using Spearmann's Rank correlation coefficient (R). All statistical analyses were performed with S-PLUS (MathSoft, Inc, Seattle, WA, USA) and Statistica ${ }^{\circledR}$ (Statsoft, Inc., Tulsa, Okla., USA, 1996).

\section{RESULTS AND DISCUSSION}

\section{Experiment 1: Tree Susceptibility During Dormancy De- velopment in Autumn}

The influence of tree growth stage in the autumn and infection environment on susceptibility of pear OHF97 rootstock to $P$. syringae was evaluated by inoculating trees at different stages of dormancy development in the autumn after terminal buds set (October to December) and maintaining trees under different environmental conditions after inoculation. Susceptibility of pear trees in the autumn to infection by $P$. syringae was influenced by environmental factors after inoculation with the pathogen. Stems from trees maintained in the LH after inoculation had larger lesions than stems on trees maintained in the $\mathrm{GH}$ after inoculation (Table 1). The environmental conditions before inoculation and when trees were inoculated also influenced lesion size (significant interaction between location before inoculation and time of inoculation). This suggests tree development (as a function of environmental conditions before and after inoculation) as well as environmental effects on the pathogen influences disease development. Lesions on trees grown in the GH were similar in size regardless of when stems were inoculated after terminal buds had set indicating trees at a similar stage of early dormancy development were equally susceptible to the pathogen regardless of the environmental conditions after inoculation. Lesions on trees grown in the lath house increased in size with increasing time after terminal buds had set (contrast $P<0.00001$ ) suggesting as trees became more susceptible as they became more dormant.

The maximum, minimum, and mean daily temperatures from October to January in the LH decreased gradually (Fig. 1A). The increase in the size of lesions on trees in the LH as they became more dormant corresponded with the decrease in temperature. The cooler environment of the $\mathrm{LH}$ after inoculation favored disease development over the warmer conditions in the $\mathrm{GH}$. When trees were maintained in the $\mathrm{GH}$ after inoculation, temperatures from October to December were relatively stable and susceptibility to the pathogen did not change during this time. When trees were in the LH before and after exposure to the pathogen (LH/LH) there were negative relationships between lesion size and maximum temperature $(\mathrm{R}=-0.5482, P<0.0001)$, minimum temperature $(\mathrm{R}=-0.5486 ; P<0.0001)$, and average temperature $(\mathrm{R}=-0.5609, P<0.0001)$ after inoculation. This negative relationship between temperature and disease severity (size of lesion) when trees were in the LH suggests the decreasing temperatures from October to December after inoculation increases tree susceptibility. In comparison, when trees from the GH and were moved to the $\mathrm{LH}$ after inocula-

Table 1. Influence of Different Environmental Conditions Prior to Inoculation and After Inoculation (After Terminal Budset) on the Size of Lesions Caused by Inoculating Wounded Pear (Pyrus communis) OHF97 Rootstock Stems with Phytophthora syringae

\begin{tabular}{|c|c|c|c|c|c|c|}
\hline \multirow{3}{*}{ Factors $^{\mathrm{z}}$} & \multirow{3}{*}{ Treatments $^{\mathbf{y}}$} & \multicolumn{5}{|c|}{ Lesion Size (cm) } \\
\hline & & \multicolumn{5}{|c|}{ Time $(\mathbf{d})^{\mathrm{x}}$} \\
\hline & & 7 & 21 & 42 & 56 & 70 \\
\hline \multicolumn{7}{|c|}{ Growing Location $x$ Time } \\
\hline & LH & $0.435 \mathrm{aA}^{\mathrm{w}}$ & $1.155 \mathrm{bA}$ & $0.940 \mathrm{bB}$ & $1.515 \mathrm{cB}$ & $1.720 \mathrm{cB}$ \\
\hline & GH & $0.485 \mathrm{aA}$ & $1.240 \mathrm{cA}$ & $0.460 \mathrm{aA}$ & $0.695 \mathrm{abA}$ & $0.915 \mathrm{bcA}$ \\
\hline \multicolumn{7}{|c|}{ Incubation Location $x$ Time } \\
\hline & LH & $0.920 \mathrm{aB}$ & $1.425 \mathrm{bB}$ & $0.695 \mathrm{aA}$ & $1.550 \mathrm{bB}$ & $1.580 \mathrm{bB}$ \\
\hline & GH & $0.000 \mathrm{aA}$ & $0.970 \mathrm{bcA}$ & $0.705 \mathrm{bA}$ & $0.660 \mathrm{bA}$ & $1.055 \mathrm{cA}$ \\
\hline \multicolumn{7}{|c|}{ Growing Location $x$ Incubation Location } \\
\hline & LH/LH & & & $1.502 \mathrm{C}$ & & \\
\hline & LH/GH & & & $0.804 \mathrm{~B}$ & & \\
\hline & GH/LH & & & $0.966 \mathrm{~B}$ & & \\
\hline & GH/GH & & & $0.552 \mathrm{~A}$ & & \\
\hline
\end{tabular}

${ }^{\mathrm{z}}$ Specific treatment comparisons evaluated using Kruskal-Wallis test for interactions between Growing Location $\mathrm{x}$ Time ( $\mathrm{n}=20$ ), Incubation Location and Time ( $\mathrm{n}=20$ ), and Growing Location $\mathrm{x}$ Incubation Location $(\mathrm{n}=50)$

${ }^{\mathrm{y}}$ Trees grown in lath house ( $\left.\mathrm{LH}\right)$ and incubated in $\mathrm{LH}$ after inoculation ( $\left.\mathrm{LH} / \mathrm{LH}\right)$, trees grown in greenhouse $(\mathrm{GH})$ and incubated in $\mathrm{GH}$ after inoculation $(\mathrm{GH} / \mathrm{GH})$, trees grown in $\mathrm{GH}$ and incubated in $\mathrm{LH}$ after inoculation $(\mathrm{GH} / \mathrm{LH})$, and trees grown in $\mathrm{LH}$ and incubated in $\mathrm{GH}$ after inoculation $(\mathrm{LH} / \mathrm{GH})$.

${ }^{\mathrm{x}}$ Time after terminal budset (1 October 2003). Trees inoculated 7 October, 21 October, 11 November, 25 November, and 9 December 2003 . Stems collected for analyses 8 weeks after inoculation.

${ }^{\mathrm{w}}$ Means followed by the same lower case letter within a row and factor are not significantly different $\left(\mathrm{K}-\mathrm{W}_{0.05}\right)$. Means followed by the same upper case letter within a column and factor are not significantly different $\left(\mathrm{K}-\mathrm{W}_{0.05}\right)$ 

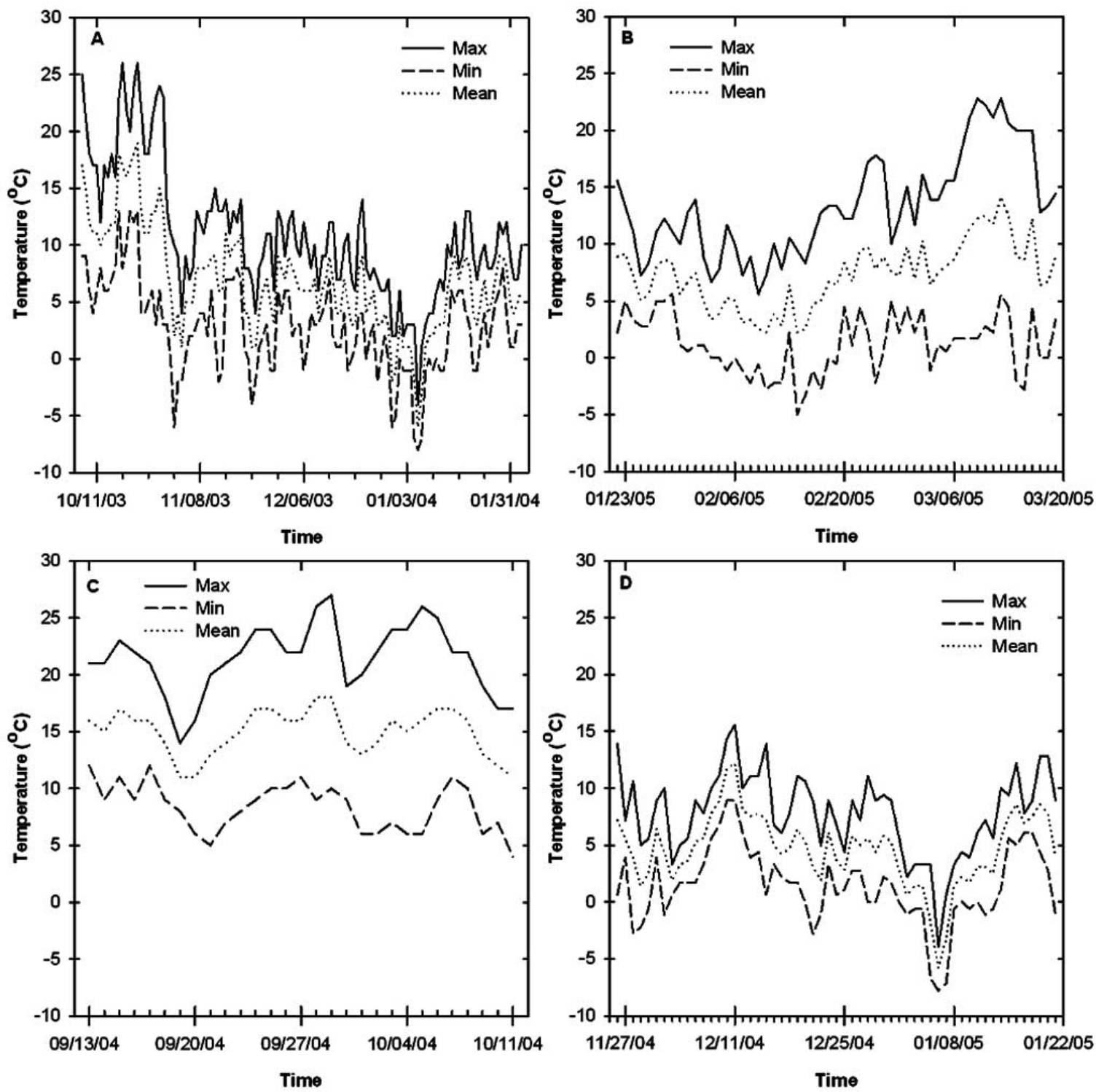

Fig. (1). Daily maximum (max), minimum (min), and mean temperature in Corvallis, OR between (A) 7 October 2003 and 3 February 2004 , (B) 22 January 2005 and 19 March 2005, (C) 13 September 2004and 11 October 2004, and (D) 26 November 262004 to 21 January 2005. Source: http://www.ocs.orst.edu (Zone 2 - Climate Data.

tion $(\mathrm{GH} / \mathrm{LH})$ there was no relationship between disease severity and temperature $(\mathrm{R}<0.24, P>0.05)$, suggesting the growth stage of the tree also played a role in disease development when temperatures were conducive to disease.

The influence of temperature on plant disease development has been reported for $P$. syringae as well as other Phytophthora species. Phytophthora syringae can actively grow in cold and wet conditions [5], similar to those frequently occurring in the autumn in the PNW. In California, cankers on almond caused by $P$. syringae are observed soon after pruning in the autumn and winter when temperatures are relatively low (mean daily temperature $5^{\circ} \mathrm{C}$ to $15^{\circ} \mathrm{C}$ ) [14]. Excised branch pieces of almond inoculated with $P$. syringae developed cankers at temperatures between $2{ }^{\circ} \mathrm{C}$ and $20{ }^{\circ} \mathrm{C}$ but not at $27{ }^{\circ} \mathrm{C}$. Suppression of $P$. cinnamomi on avocado (Persea americana L.) seedlings has been correlated with temperature influencing mycelial growth [15].
Our results suggest both temperature and tree growth stage play a role in susceptibility of pear trees to $P$. syringae in the autumn after terminal bud set. Leaves on trees maintained in the GH before and after exposure to the pathogen $(\mathrm{GH} / \mathrm{GH})$ did not senesce, whereas leaves on trees grown in the $\mathrm{GH}$ before inoculation and moved to the $\mathrm{LH}$ after inoculation $(\mathrm{GH} / \mathrm{LH})$ abscised in late-December and leaves on trees maintained in the $\mathrm{LH}$ before and after inoculation $(\mathrm{LH} / \mathrm{LH})$ abscised from mid- to late-November. Leaves on trees maintained in the $\mathrm{GH}$ did not senesce because leaf senescence and abscission in pear trees occurs in response to low temperature and progresses with development of dormancy [16]. These observations on differences in leaf abscission between trees in the different treatments suggest trees in the different treatments were at different stages in dormancy development when inoculated and when assessed for disease development. For example, trees grown in the $\mathrm{LH}$ before inoculation may have been in later stages of dor- 
mancy development than trees grown in the GH before inoculation. Similarly, trees in the grown in the LH before inoculation and maintained in the LH after inoculation may have been in later stages of dormancy development after inoculation than trees grown in the $\mathrm{GH}$ and moved to the $\mathrm{LH}$ after inoculation.

Dormancy development involves a multitude of plant anatomical and biochemical changes in response to ontogeny and environmental stimuli. Even though the terminal buds had set on trees in the $\mathrm{GH}$ and the LH, physiological differences between the trees, resulting from differences in dormancy development, may have made trees in the LH/LH treatment more susceptible to $P$. syringae than trees in the $\mathrm{GH} / \mathrm{LH}$ treatment. The leaves on trees in the $\mathrm{LH} / \mathrm{LH}$ treatment senesced before leaves on trees in the GH/LH treatment, suggesting trees in the $\mathrm{LH} / \mathrm{LH}$ treatment may have developed dormancy earlier than trees in the GH/LH treatments. Differences in the $\mathrm{N}$ concentration in stems may be one possible explanation for differences in susceptibility between trees in the LH/LH and GH/LH treatments. Mobilization of leaf $\mathrm{N}$ to the stems and roots of trees occurs during leaf senescence $[17,18]$, resulting in increased $N$ content of stems. Earlier leaf abscission on trees in the LH/LH treatment may have resulted in higher $\mathrm{N}$ concentrations in inoculated stems than stems on trees in the GH/LH treatment. Our previous research indicated the $\mathrm{N}$ status of pear trees stems is positively related with disease development by $P$. syringae [19]. Larger lesions on trees in the LH/LH treatment than trees in the GH/LH treatment may be due to higher $\mathrm{N}$ status in stems from earlier $\mathrm{N}$ mobilization from leaves.

\section{Experiment 2: Tree Susceptibility and Infection Envi- ronment in Winter}

The influence of tree growth stage and infection environment on susceptibility of pear trees to $P$. syringae was evaluated using trees maintained under different environmental conditions during the autumn after terminal bud set. Tree stems were inoculated in January to determine whether tree growth stage or environmental conditions after inoculation influenced tree response to the pathogen in winter. Stems from trees grown in the $\mathrm{GH}$ before inoculation had smaller lesions compared to stems on trees grown in the $\mathrm{LH}$ (Table 2). Trees moved in the CR after inoculation developed larger lesions than trees maintained in the $\mathrm{LH}$ or GH. When trees were grown in GH before inoculation, there was no difference in lesion size when trees were maintained in the $\mathrm{LH}(\mathrm{GH} / \mathrm{LH})$ or $\mathrm{GH}(\mathrm{GH} / \mathrm{GH})$ after inoculation. When trees were grown in the $\mathrm{LH}$ before inoculation, lesions were larger on trees maintained in the $\mathrm{LH}$ after inoculation $(\mathrm{LH} / \mathrm{LH})$ than lesions on trees maintained in the $\mathrm{GH}$ $(\mathrm{LH} / \mathrm{GH})$. The temperature in the $\mathrm{GH}$ and $\mathrm{CR}$ varied less than $5{ }^{\circ} \mathrm{C}$ after trees were inoculated while in the $\mathrm{LH}$ the minimum, maximum, and average daily temperature varied by almost $15{ }^{\circ} \mathrm{C}$ (Table 2 ) and gradually increased after trees were inoculated (22 January to 19 March 2005) (Fig. 1B).

These results support the results from Experiment 1, indicating a negative relationship between temperature and disease activity by $P$. syringae on pear trees exists when trees are dormant. Lesions on stems from trees maintained in the cooler conditions in the LH after inoculation (max., min., and mean temperatures of $13{ }^{\circ} \mathrm{C}, 1{ }^{\circ} \mathrm{C}$, and $7{ }^{\circ} \mathrm{C}$, respectively) were larger than lesions on trees maintained in warmer conditions in the $\mathrm{GH}$ ( $\max$, min, and mean temperature of $21{ }^{\circ} \mathrm{C}, 15^{\circ} \mathrm{C}$, and $18{ }^{\circ} \mathrm{C}$, respectively). These results confirm the findings of others who have reported a relationship between low temperature and infection by $P$. syringae in the field $[5,10,11,20]$. Lower temperatures in the CR and LH after inoculation may have resulted in greater pathogen activity than the warmer conditions in the GH.

It is also possible the warmer temperatures in the $\mathrm{GH}$ after trees were inoculated were not favorable for the pathogen [10]. Isolation of the pathogen during late spring and summer from stems of almond trees was not successful [10]. Higher temperatures in the $\mathrm{GH}$ in our experiment may also have promoted stem wounds to heal; thus decreasing the ability of the pathogen to penetrate the stem. The development of wound resistance is related to the formation of wound periderm or the infusion of lignin, suberin, waxes, and wound gums in the layers of cells immediately subtending the wound surface. Resistance of wounds to fungal infection increases as wounds age $[10,11,21,22]$ and the rate of deposition of lignin and suberin in the wound depends on the time of the year [23], and temperature [11] when wounds are inflicted. Actively growing trees generally have a more rapid response to wounding than trees undergoing dormancy. Wound cork layers on apple bark form more quickly in summer compared to winter [24] and low temperature slows down lignin and suberin formation in almond stem wounds, resulting in low disease resistance [14].

Table 2. Influence of Different Environmental Conditions Prior to Inoculation and After Inoculation on The Size of Lesions Caused by Inoculating Wounded Pear (Pyrus communis) OHF97 Rootstock Stems with Phytophthora syringae and Placing Trees in Locations with Different Minimum, Maximum, and Mean Temperatures

\begin{tabular}{|c|c|c|c|c|c|c|c|}
\hline \multirow{2}{*}{\begin{tabular}{|c} 
Location After Inoculation $^{\mathrm{z}}$ \\
GH2
\end{tabular}} & \multicolumn{4}{|c|}{ Lesion Size $(\mathbf{c m})^{y}$} & \multicolumn{3}{|c|}{ Temperature $\left({ }^{\circ} \mathbf{C}\right)^{\mathrm{w}}$} \\
\hline & \multicolumn{2}{|c|}{ LH1 } & \multicolumn{2}{|c|}{ GH1 } & $\begin{array}{c}\text { Minimum } \\
15.0\end{array}$ & $\begin{array}{c}\text { Maximum } \\
21.0\end{array}$ & $\begin{array}{r}\text { Mean } \\
18.0\end{array}$ \\
\hline LH2 & 3.800 & $\mathrm{bB}$ & 1.020 & $\mathrm{aA}$ & 1.0 & 13.0 & 7.0 \\
\hline CR2 & 4.990 & $\mathrm{cB}$ & 2.600 & $\mathrm{bA}$ & 4.0 & 4.0 & 4.0 \\
\hline
\end{tabular}

${ }^{\mathrm{z}}$ Trees maintained in lath house (LH2), greenhouse (GH2), or cold room (CR2) after inoculation on 22 January 2005. Stems collected for analyses 8 weeks after inoculation.

${ }^{\mathrm{y}}$ Trees maintained in lath house (LH1) or greenhouse (GH1) from 30 October 2004 to 22 January 2005.

${ }^{\mathrm{x}}$ Means $(\mathrm{n}=10)$ followed by the same lower case letter within a column are not significantly different $\left(\mathrm{THSD}_{0.05}\right)$. Means followed by the same upper case letter within a row are not significantly different $\left(\mathrm{THSD}_{0.05}\right)$.

${ }^{\text {w} A v e r a g e ~ d a i l y ~ m a x i m u m, ~ m i n i m u m, ~ a n d ~ m e a n ~ t e m p e r a t u r e ~ b e t w e e n ~} 22$ January and 19 March 2005 in the GH, LH, and CR after inoculation with pathogen. 
In our experiment, leaves on trees in the LH had abscised before trees were inoculated and leaves were still present on trees in the GH when they were inoculated. Smaller lesions on trees grown in the GH than trees grown in the LH may be a result of differences in stem $\mathrm{N}$ content (as described above); however, the ability of the trees in the GH to respond to stem wounding may also be higher than trees grown in the LH. The differences in tree susceptibility to $P$. syringae may therefore be a direct result of temperature on the pathogen or and indirect effect on the pathogen through the effects of temperature on plant metabolic activity.

During production, it is probably impossible to separate the effects of temperature on tree growth status and metabolic activity and tree susceptibility to $P$. syringae. Trees may be exposed to the pathogen when they are in different stages or dormancy (as in Experiment 1 and 2). In both cases, however, the temperatures after exposure to the pathogen appear to be extremely important for disease development.

\section{Experiment 3: Susceptibility of Actively Growing Trees}

The influence of infection environment on susceptibility of pear trees to $P$. syringae was evaluated using actively growing trees maintained under different environmental conditions after inoculation. Tree stems were inoculated in September to determine whether environmental conditions after inoculation influence tree response to the pathogen before terminal bud set. When actively growing trees were inoculated with $P$. syringae before bud set, trees maintained in the GH and the LH after inoculation developed smaller lesions than trees moved to the CR (Table $\mathbf{3}$ ). The size of lesions on trees in the LH and in the GH was similar. After trees were inoculated differences between maximum and minimum daily temperatures in the $\mathrm{GH}$ and $\mathrm{CR}$ were less than $5{ }^{\circ} \mathrm{C}$ and differences between maximum and minimum daily temperatures in the LH was $\sim 14{ }^{\circ} \mathrm{C}$ (Table 3). The temperature after inoculation remained relatively constant in the LH with mean, maximum, and minimum temperatures varying by less than $5{ }^{\circ} \mathrm{C}$ (Fig. 1C).

These results support the results from Experiment 1 and 2 , indicating temperature after inoculation with $P$. syringae has a strong influence on disease development, regardless of whether the trees are in different stages of dormancy (Experiment 1 and 2) or whether trees are actively growing (Experiment 3). Temperatures after inoculation were lower in the CR than in the GH and $\mathrm{LH}$ and this difference in temperature after inoculation may have resulted in the differences in lesion size between the treatments. Additionally, these results, combined with our results from Experiment 1 and Experiment 2 indicate the magnitude of the response of trees to the pathogen and temperature varies depending upon the growth status of the trees.

Our results support previous reports from field studies of $P$. syringae actively causing disease in cold conditions $[5$, $10,11,20]$. With pear trees, we also determined that the pathogen can cause disease in both actively growing and dormant trees if the temperatures after exposure to the pathogen are conducive to pathogen activity and when temperatures increase tree susceptibility. Similarly dormant lilac plants were also reported to be more susceptible to $P$. syringae than actively growing plants; however, the pathogen could still infect actively growing plants under certain conditions [25]. The seasonal activity of the host and the influence of environmental factors such as temperature determine the time course of epidemics caused by Phytophthora spp. [9]. In rhododendrons, infection by $P$. syringae only occurred when dormant portions of the plants were inoculated, and infection failed to occur when actively growing portions of the plants were inoculated, even under low temperatures [8]. Phytopthora syringae was not able to infect lilac [12], apple $[25,26]$ and almond [10] during the summer. Under natural conditions, the lack of disease caused by $P$. syringae in summer and susceptibility of dormant plant tissue may be coincidental to the effects of temperature on plant growth and pathogen activity. Our results indicate both actively growing and dormant pear trees are susceptible to $P$. syringae when they were placed into a cold room after inoculation. These results suggest temperature after exposure of the tree to the pathogen was more important than tree growth status.

\section{Experiment 4: Relationships Between Susceptibility, Tree N Status, and Wound Age}

The influence of tree $\mathrm{N}$ status and wound age on susceptibility of pear trees to $P$. syringae was evaluated by spraying trees with Urea+CuEDTA in the autumn after terminal bud set and wounding the stems at different times before inoculation as trees developed dormancy in the autumn. When trees were maintained in the LH after inoculation, $0 \mathrm{~d}$ and $1 \mathrm{~d}$ old wounds had the highest disease incidence and largest lesions

Table 3. Influence of Different Environmental Conditions After Inoculation on the Size of Lesions Caused by Inoculating Actively Growing Wounded Pear (Pyrus communis) OHF97 Rootstock Stems with Phytophthora syringae and Placing trees in Locations with Different Minimum, Maximum, and Mean Temperatures

\begin{tabular}{|c|c|c|c|c|c|}
\hline \multirow{2}{*}{ Location After Inoculation $^{z}$} & \multicolumn{2}{|c|}{ Temperature $\left({ }^{\circ} \mathbf{C}\right)^{\mathrm{x}}$} \\
\cline { 2 - 6 } & \multicolumn{2}{|c|}{ Lesion Size (cm) } & Minimum & \multicolumn{2}{c|}{ Maximum } \\
\hline GH & 0.837 & $\mathrm{a}^{\mathrm{y}}$ & 15.0 & 21.0 & 22.0 \\
\hline LH & 1.075 & $\mathrm{a}$ & 8.0 & 4.0 & 15.0 \\
\hline CR & 5.850 & $\mathrm{~b}$ & 4.0 & 4.0 & 4.0 \\
\hline
\end{tabular}

${ }^{\mathrm{z}}$ Trees moved to a greenhouse (GH), lath house (LH) or cold room after inoculation 13 September 2004. Stems collected for analyses on 11 October 2004.

${ }^{\mathrm{y}}$ Means $(\mathrm{n}=8)$ followed by the same lower case letter within a column are not significantly different $\left(\mathrm{K}-\mathrm{W}_{0.05}\right)$.

${ }^{\mathrm{x}}$ Average daily maximum, minimum and mean temperature between 13 September 2004 and 11 October 2004 in the GH, LH, and CR after inoculation with pathogen. 
and wounds $7 \mathrm{~d}$ old and older had lower disease incidence and smaller lesions (Table 4). Similarly, when trees were moved to the CR after inoculation, $0 \mathrm{~d}$ and $1 \mathrm{~d}$ old wounds had the highest disease incidence and largest lesions and wounds $7 \mathrm{~d}$ old and older had the lowest disease incidence and smallest lesions. Moving trees to the CR increased disease incidence in $1 \mathrm{~d}$ and $7 \mathrm{~d}$ old wounds, increased the size of lesions in $1 \mathrm{~d}$ old wounds, and decreased the size of lesions in fresh $\left(\begin{array}{ll}0 & \mathrm{~d}\end{array}\right)$ wounds. Spraying trees with Urea+CuEDTA had no influence on disease incidence of trees maintained in the $\mathrm{LH}$ or $\mathrm{CR}$ after inoculation and no influence on the size of lesions when trees were maintained in the LH after inoculation (Table 4). Spraying trees with Urea+CuEDTA decreased the size lesions on trees moved to the CR after inoculation.

The temperature in $\mathrm{CR}$ was $4^{\circ} \mathrm{C}$ during the experiment. In the LH the daily minimum, maximum, and mean temperature between when trees were inoculated and the end of experiment varied by $\sim 6{ }^{\circ} \mathrm{C}$ after inoculation (Fig. 1). The average minimum, maximum, and average daily temperature during the 8 weeks after inoculation was $7.8{ }^{\circ} \mathrm{C}, 1.4{ }^{\circ} \mathrm{C}$, and $4.6{ }^{\circ} \mathrm{C}$, respectively.

Wound age had a significant influence on the susceptibility of pear stems to infection by $P$. syringae. Fresh wounds inoculated with $P$. syringae developed lesions, and as wounds became older they became less susceptible to infection. Surface wounds inflicted during harvest and leaf scars caused by chemical defoliation or natural defoliation may serve as the infection openings for P. syringae [5, 12]; however our data indicate the length of time between wound formation and exposure to the pathogen dictates whether infection will occur.

Others have reported nearly all cankers on almond trees caused by $P$. syringae are associated with pruning wounds or injuries created during pruning in late autumn and winter, and infection is unsuccessful on uninjured bark [10]. Fresh wounds on almond have also been reported to be more susceptible to infection by $P$. syringae compared to aged wounds [11]. The development of wound resistance is related to the formation of wound periderm or the infusion of lignin, suberin, waxes, and/or wound gums in the layers of cells immediately subtending the wound surface, and resistance to pathogen infection generally increases as wounds age $[10,14,21,23]$. The rate deposition of lignin and suberin in the wound depended on the time of the year and temperature when wound are inflicted [11]. Wound cork layers on apple bark formed quickly in summer than winter [24]. Low temperature slowed down lignin and suberin formation in almond wounds, resulting in reduced disease resistance [14].

Our data indicate the influence of wound age on susceptibility of pear stems to $P$. syringae was not influenced by the specific environmental conditions after inoculation in our study. It is possible the relatively low temperatures during incubation in both $\mathrm{LH}$ ( $\max , \mathrm{min}$, and mean temperature of $7.8^{\circ} \mathrm{C}, 1.4{ }^{\circ} \mathrm{C}$, and $4.6^{\circ} \mathrm{C}$, respectively) and $\mathrm{CR}\left(4{ }^{\circ} \mathrm{C}\right)$ were favorable for the pathogen. Phytophthora syringae activity is restricted to cold climates and it is most active during the cool, rainy months of the year (September to November in

Table 4. Influence of Spraying Foliage with a Combination of Urea and Copper Chelate (CuEDTA) in October on the Size of Lesions and Disease Incidence Caused by Inoculating Wounded Pear (Pyrus communis) OHF97 Rootstock Stems with Phytophthora syringae Either 0, 1, 7, 14, 21, or 28 d After Wounding and Storing Trees in a Lathhouse (LH) or Cold Room (CR)

\begin{tabular}{|c|c|c|c|c|c|}
\hline \multirow{2}{*}{ Factors $^{\mathrm{z}}$} & \multirow{2}{*}{ Treatments $^{\mathrm{y}}$} & \multicolumn{2}{|c|}{ Lesion Size (cm) } & \multicolumn{2}{|c|}{ Disease Incidence (\%) } \\
\hline & & $\mathbf{L H}$ & $\mathbf{C R}$ & $\mathbf{L H}$ & $\mathbf{C R}$ \\
\hline \multicolumn{6}{|c|}{ Urea $x$ Incubation Location } \\
\hline & Water & $1.669 \mathrm{aA}^{\mathrm{x}}$ & $2.252 \mathrm{bB}$ & $35.4 \mathrm{aA}^{\mathrm{x}}$ & $41.7 \mathrm{aA}$ \\
\hline & Urea & $1.727 \mathrm{aA}$ & $1.812 \mathrm{aA}$ & $33.3 \mathrm{aA}$ & $45.8 \mathrm{aA}$ \\
\hline \multicolumn{6}{|c|}{ Wound Age $x$ Incubation Location } \\
\hline & $\mathbf{0}$ & $7.300 \mathrm{cB}$ & $5.900 \mathrm{bA}$ & $100.0 \mathrm{bA}$ & $100.0 \mathrm{cA}$ \\
\hline & 1 & $2.500 \mathrm{bA}$ & $5.056 \mathrm{bB}$ & $81.2 \mathrm{bA}$ & $100.0 \mathrm{cB}$ \\
\hline & 7 & $0.218 \mathrm{aA}$ & $0.912 \mathrm{aA}$ & $12.5 \mathrm{aA}$ & $43.7 \mathrm{bB}$ \\
\hline & 14 & $0.169 \mathrm{aA}$ & $0.325 \mathrm{aA}$ & $12.5 \mathrm{aA}$ & $18.7 \mathrm{aA}$ \\
\hline & 21 & $0 \mathrm{aA}$ & $0 \mathrm{aA}$ & $0 \mathrm{aA}$ & $0 \mathrm{aA}$ \\
\hline & 28 & $0 \mathrm{aA}$ & $0 \mathrm{aA}$ & $0 \mathrm{aA}$ & $0 \mathrm{aA}$ \\
\hline
\end{tabular}

${ }^{\mathrm{z}}$ Specific treatment comparisons evaluated using Kruskal-Wallis test for interactions between Urea $\mathrm{x}$ Incubation Location ( $\left.\mathrm{n}=48\right)$ and Wound Age $\mathrm{x}$ Incubation Location ( $\mathrm{n}=16$ ).

${ }^{\mathrm{y}}$ Trees sprayed with water (Water), or a combination of $3 \%$ urea solution with $1 \%$ CuEDTA (Urea) on 22 October 2004 and wounded on 29 October (28 d), 5 November ( 21 d), 12 November $(14 \mathrm{~d}), 19$ November $(7 \mathrm{~d})$, and 25 November $(0 \mathrm{~d})$ before inoculation with pathogen and maintained for 8 weeks in a lath house (LH) or coldroom $(\mathrm{CR})$. Stems collected for analyses on 21 January 2005.

${ }^{\mathrm{x}}$ Means followed by the same lower case letter within a column and factor or followed by the same upper case letter within a variable, row, and factor are not significantly different (K-W $\mathrm{W}_{0.05}$ ). 
the northern hemisphere) $[4,5]$. Phytophthora syringae can cause cankers on almond branch segments at temperatures between $2{ }^{\circ} \mathrm{C}$ to $20{ }^{\circ} \mathrm{C}$ but not at $27{ }^{\circ} \mathrm{C}$ [10]. The development of resistance to infection by $P$. syringae on bark wounds of almond trees is slowed when temperatures are low [11]. In our study the average daily temperature in the $\mathrm{CR}$ and the $\mathrm{LH}$ after inoculation were similar $\left(<1{ }^{\circ} \mathrm{C}\right.$ difference) and differences between the LH and the CR after inoculation were less than $4{ }^{\circ} \mathrm{C}$. This similarity in temperature between the two environmental conditions after inoculation could account for the similarity in disease incidence and lesion size on stems in the two locations.

Our data indicate the influence of wound age on susceptibility of pear stems to $P$. syringae was not influenced by spraying trees with Urea+CuEDTA. Across all wound ages, stems on trees sprayed with Urea+CuEDTA or water had similar disease incidence and lesion size, suggesting Urea+CuEDTA did not physiologically alter pear tree susceptibility to $P$. syringae infection. Others have reported immature leaf scars, remaining after early defoliation, can serve as primary avenues for infection by $P$. syringae $[5,11$, 12]. In our study, only wounds on pear stems were inoculated with the pathogen and not leaf scars; therefore our results do not address whether the physical changes due to Urea+CuEDTA influence trees susceptibility to $P$. syringae.

\section{CONCLUSIONS}

In summary, using a simple disease assay system we determined the susceptibility of pear trees to $P$. syringae varies between actively growing and dormant trees, and incubation conditions after exposure to the pathogen, particularly temperature, are important for disease development regardless of tree growth stage. Under conditions favorable to the pathogen, $P$. syringae can infect stems of both actively growing and dormant pear trees. The ability of $P$. syringae to infect wounds on stems of pear may be restricted by the age of the wound, even in dormant trees. In our test conditions, as trees became more dormant in the autumn their susceptibility to $P$. syringae was not increased by the influence of urea of tree $\mathrm{N}$ status. This information is useful to nursery management practices in areas infested with $P$. syringae or during transport or cold storage when the potential for exposure to the pathogen is high and highlights the important of inspection and treatment of both dormant and actively growing trees to prevent or reduce the build up of inoculum and avoid epidemics.

\section{ACKNOWLEDGEMENTS}

This work was funded, in part, by the United States Department of Agriculture, Agricultural Research Service (USDA-ARS), Northwest Center for Nursery Crop Research (Specific Cooperative Agreement Number 5358-12210-00302).

Mention of a trademark, proprietary product, or vendor does not constitute a guarantee or warranty of the product by the U.S. Dept. of Agriculture and does not imply its approval to the exclusion of other products or vendors that also may be suitable.

\section{REFERENCES}

[1] Tidball CJ, Linderman RG. Phytophthora root and stem rot of apple rootstocks from stool beds. Plant Dis 1990; 74:141-6.

[2] Jeffers SN, Aldwinckle HS. Seasonal variation in extent of colonization of two apple rootstocks by five species of Phytophthora. Plant Dis 1986; 70: 941-5.

[3] McIntosh DL, MacSwan 1C. The occurrence of collar rot caused Phytophthora cactorum in a planting of apple trees aged 1 to 7 years. Plant Dis Rep 1966; 50: 267-70.

[4] Erwin DC, Ribeiro OK. Phytophthora diseases worldwide. St. Paul, Minnesota: APS Press1996.

[5] Pscheidt JW, Ocamb CM. Pacific northwest plant disease management handbook. Oregon State University: Corvallis, OR, USA 2002.

[6] Awan AB, Struchtemeyer RA. The effect of fertilization on the susceptibility of potatoes to late blight. Am Potato J 1957; 34: 3159 .

[7] Choi D, Ward BL, Bostock RM. Differential induction and suppression of potato 3-hydroxy-3-methylglutaryl coenzyme A reductase genes in response to Phytophthora infestans and its elicitor arachidonic acid. Plant Cell 1992; 4: 1333-44.

[8] Linderman RG. Phytophthora syringae blight. In: Coyier DL, Roane MK, Eds. Compendium of diseases of azalea and rhododendron. St. Paul, Minn esota, USA: APS Press 1986; pp. 15-7.

[9] Duniway JM. Role of physical factors in the development of Phytophthora diseases. In: Erwin DC, Bartnicki-Garcia S, Tsao PH, Eds. Phytophthora: its biology, taxonomy, ecology, and pathology. St. Paul, MN, USA: APS Press 1983; pp. 175-87.

[10] Bostock RM, Doster MA. Association of Phytophthora syringae with pruning wound cankers of almond trees. Plant Dis 1985; 69: 568-71.

[11] Doster MA, Bostock RM. Effect of low temperature on resistance of almond trees to Phytophthora pruning wound cankers in relation to lignin and suberin formation in wounded bark tissue. Phytopathol 1988; 78: 478-83.

[12] De Bruyn HL. The Phytophthora disease of lilac. Phytopathol 1924; 14: 503-17.

[13] Lalancette N, Robison DM. Effect of fungicides, application timing, and canker removal on incidence and severity of constriction canker of peach. Plant Dis 2002; 86: 721-8.

[14] Doster MA, Bostock RM. Susceptibility of almond cultivars and cankers and stone fruits species to pruning wound cankers caused by Phytophthora syringae. Plant Dis 1988; 2: 490-2.

[15] Zentmeyer, GA. 1980. Phytophthora cinnamomi and the diseases it causes. Monogr. 10. Amer. Phytopathol. Soc., St. Paul, MN, USA.

[16] Heide OM, Prestrud AK. Low temperature, but not photoperiod, controls growth cessation and dormancy induction and release in apple and pear. Tree Physiol 2005; 25: 109-14.

[17] Keskitalo J, Bergquist G, Gardeström P, Jansson S. A cellular timetable of autumn senescence. Plant Physiol 2005; 139: 1635-48.

[18] Titus JS, Kang SM. Nitrogen metabolism, translocation, and recycling in apple trees. Hort Rev 1982; 4: 204-46.

[19] Laywisadkul S, Scagel CF, Fuchigami LH, Linderman RG. 2010. Spraying leaves of pear nursery trees with urea and copper EDTA alters tree nitrogen concentration without influencing tree susceptibility to Phytophthora syringae. Hortechnology 2010; 10: (In press).

[20] Edney KL. The infection of apples by Phytophthora syringae. Ann Appl Biol 1978; 88: 31-6.

[21] Biggs AR. Wound age and infection of peach bark by Cytospora leucostoma. Can J Bot 1986; 64: 2319-21.

[22] Bostock RM, Middleton GE. Relationship of wound periderm formation to resistance to Ceratocystis fimbriata in almond bark. Phytopathol 1987; 77: 1174-80.

[23] Bostock RM. Stermer BA. Perspectives on wound healing in resistance to pathogens. Ann Rev Phytopathol 1989; 27: 343-71.

[24] Tamura O, Saito I. Histopathological changes of apple bark infected by Valsa ceratosperma (Tode ex Fr.) Maire during dormant and growing period. Ann Phytopath Soc Jpn 1982; 48: 490-8. 
[25] Sewell GWF, Wilson JF. Phytophthora collar rot of apple: seasonal effects on infection and disease development. Ann Appl Biol 1973; 74: $149-58$.
[26] Sewell GWF, Wilson JF, Dakwa T. Seasonal variations in the activity in soil of Phytophthora cactorum, $P$. syringae and P. citricola in relation to collar rot disease of apple. Ann Appl Biol 1974; 76: $179-86$.

Received: November 17, 2009

Revised: December 23, 2009

Accepted: January 01, 2010

(C) Laywisadkul et al.; Licensee Bentham Open.

This is an open access article licensed under the terms of the Creative Commons Attribution Non-Commercial License (http://creativecommons.org/licenses/ by-nc/3.0/) which permits unrestricted, non-commercial use, distribution and reproduction in any medium, provided the work is properly cited. 